\title{
Bilingualism in the Cambrai Homily
}

\author{
Gwendolyne Knight*
}

The Cambrai Homily (Cambrai, Bibliothèque municipale, MS 679 [s. viii2] ff. $37 \mathrm{rb}-38 \mathrm{rb}$ ) is a short prose homily found between two chapters of the Collectio canonum Hibernensis; as the Homily is incomplete, it has been suggested that it was copied from a stray leaf inserted into the exemplar of the Collectio. The Homily itself is estimated to date to the seventh or first half of the eighth century. More salient for the purpose of this anthology, however, is the fact that the Homily code-switches between Latin and Old Irish. Some claim that this text provides us with the earliest record of continuous Irish prose; as such it has long been an important source for early Irish linguistics, as well as evidence for sermons in the seventh-century Irish Church. Nevertheless, the aspects of code-switching between Old Irish and Latin in the Cambrai Homily remain underexplored. This article provides an assessment of existing perspectives on the relationship between Latin and Old Irish in this homily, and offers a fresh interpretation of the code-switching that takes place.

Keywords: Medieval homily, code-switching, translation studies, Old Irish, Latin, Cambrai

\section{Introduction}

The manuscript preserved in Cambrai, Bibliothèque municipale, MS 679 (formerly 619) is a partial transmission of the Collectio canonum Hibernensis, containing 38 of 65-69 books of scriptural and patristic extracts, as well as canon law, and Irish synodal and penitential decrees. It was copied for Alberic, bishop of Cambrai and Arras (763-790), in the second half of the 8th century. The Collectio is entirely in Latin, and littered with scribal errors, potentially due to the scribe's difficulty with the Irish script of the exemplar. ${ }^{1}$ The scribe appears to have had particular difficulty with a certain section of text, at folios $37 \mathrm{rb}-38 \mathrm{rb}$, which contains an incomplete homily, mostly in Irish with some elements in Latin. This text, known as the Cambrai Homily, was most likely inserted into the exemplar as a flyleaf, which the scribe copied along with the rest of the codex.

The Cambrai Homily not only lays claim to being one of the earliest preserved examples of continuous Irish prose, but also demonstrates an early example of Irish-Latin codeswitching. These features, in combination with the Homily's somewhat enigmatic classification of martyrdom, have piqued the interest of scholars from various disciplines. It is clear that in the Cambrai Homily we are dealing with a piece of writing that is actively engaging in code-switching. Nevertheless, the phenomenon of code-switching within the Cambrai Homily remains comparatively understudied, and there remains space for examining the language interactions present in the text. Indeed, the precise motivation, function and effect of these switches remain elusive. It has been suggested that the Latin quotations amount to little more than authoritative citations that need to be translated for an audience ill-equipped to understand them, although the exegetical complexity has been cited as an indication that

* Correspondence details: Gwendolyne Knight, Stockholm University. Email: gwendolyne.knight@historia.su.se.

1 Muzerelle, Manuscrits, 87; Ó hAnnracháin, Aguisín I, 40; Stokes and Strachan, Description, xxvi. 
the Homily was more likely to have been composed for a monastic audience. ${ }^{2}$ Even though the role of translation is downplayed, the longer passages in Irish are still proposed to serve as elucidation for difficult concepts. The present article builds on recent work on Irish-Latin code-switching to offer a fresh perspective on the language interactions within this text. ${ }^{3}$ In particular, it examines instances of what had been identified as translation, and posits that these may be better explained as examples of multilingual reiteration, thus reinforcing both the potential for a highly competent bilingual speech community as well as the likelihood that the Homily was composed for a predominantly monastic audience.

\section{The Cambrai Homily}

The Cambrai Homily begins with an invocation (In nomine Dei summi), followed by the pericope, a quotation in Latin from Scripture (Matthew 16.24, Siquis uult post me uenire, abneget semet ipsum et tollat crucem suam, et sequatur me, "Then said Jesus unto his disciples, If any man will come after me, let him deny himself, and take up his cross, and follow me«). ${ }^{4}$ As Pádraig Ó Néill observes, this quotation provides not only the point of departure but also the thesis of the homily. ${ }^{5}$ Then follows the exordium in Irish, which identifies the speaker of the quotation (i.e. Christ) and his audience (all people), as well as the intention of the utterance (to banish vice and sin on the one hand, and gather virtue on the other). The body of the homily follows. It begins with the Irish isaire asber, "therefore he says « and a repetition of the quotation in Latin, with partial translations into Irish:

\section{Siquis uult post me uenire abneget semet ipsum et tollat crucem suam ocuis ticsath a chruich et sequatur me ocuis numsechethse}

"If any man will come after me, let him deny himself, and take up his cross, and let him take up his cross, and follow me, and let him follow me."

The homilist continues in Irish, setting out the ways in which one denies oneself (i.e. not giving in to our desires and abjuring our sins) and the ways in which one takes up one's cross and follows Christ (i.e., through abstinence, fellow-suffering, and martyrdom).

2 Ó Néill initially writes that "This interchange between the functions of the two languages [i.e., Latin and Old Irish] would suggest an audience which did not understand Latin and needed to have the important points of the homily explained to them in their native language." However, he considers the discussion of martyrdom better suited to a monastic community, and ultimately proposes a predominantly monastic audience that potentially included laypeople: Ó Néill, Background, 144-145. For the latter argument, see additionally Picard, L’Homélie de Cambrai.

3 Most prominently Bisagni, Proglomena; Ó Flaithearta and Nooj, Code-Switching (including articles from both Stam and ter Horst); Stam, Typology; ter Horst, Code-switching; Stam and ter Horst, Visual Diamorphs.

4 All scriptural quotations and quotations from Irish maintain the form of the textus restitutus of Stokes and Strachan, 2. Cambrai Homily; translations into English of scriptural quotations are taken from the King James Version. Translations of other Latin quotations are my own unless otherwise indicated. Translations from Irish are my own, based on those found in Stokes and Strachan. For clarity, quotations in Irish are given in italics; quotations in Latin are given underlined.

5 Ó Néill, Background, 138. 
The Irish phrase amail assindber alaile, "like a certain person says it", introduces a supporting quotation in Latin from Gregory the Great. Gregory is not identified as its source, but Jean Michel Picard rightly points out that this passage is part of a piece of exegesis that was well known in monastic environments in the late seventh and early eighth centuries, and Ó Néill has also observed that the writings of Gregory the Great enjoyed great popularity among Irish ecclesiastics more generally. ${ }^{6}$ Indeed, this citation provides, as Picard writes, the keys to the homilist's discourse in more ways than one. ${ }^{7}$ Firstly, the citation describes the two ways in which we may carry the Lord's cross: through fleshly abstinence and through fellow-suffering. Secondly, however, the homilies that inform both this citation and the Cambrai Homily more broadly (Homilies 32 and 37 from Gregory's Homilia, discussed in more detail below) centre on the theme of martyrdom, the theme to which the homilist turns in the second part of the Cambrai Homily.

The Latin phrase ut Paulus ait, "as Paul says « transitions to a Pauline quotation which is cited in support of fellow-suffering (Galatians 6.2). A line nearly entirely in Irish (ocus asbeir daniu ind apostol, "and furthermore the apostle says «) $)^{8}$ introduces two further quotations (Romans 12.15 and I Corinthians 12.26), which speak further to the theme of sharing in the joy, as well as the suffering, of one's fellow humans, and establish the metaphor of the mystical body. A section then follows in Irish that expands upon this metaphor; i.e., that all humans are members in the body of Christ. This concludes with an introduction in Irish, amail assindbeir apostolus, "like the apostle says it", to a citation of Paul (II Corinthians 11.29). ${ }^{9}$ The quotation is expanded on in Irish and the whole section on fellow-suffering brought to a conclusion by the phrase adciam isnaib inscib sc[e]o eulis ind aecni as ar chenél cruche adrimther in coicsath, "we see in the words and wisdom of the sage that fellow-suffering is counted as a kind of cross«.

8 The ligature form apostol appears in the manuscript: Cambrai, Bibliothèque municipale, MS 679, fol. 37d; Ó hAnnracháin, Aguisín I, 41 (37 verso is incorrectly identified as 37 recto). Stokes and Strachan retain the ligature in their lectio codicis; however, the textus resitutus removes the ligature and Stokes and Strachan appear to interpret apostol as Irish. I am grateful to the peer reviewer for pointing out that the Irish forms apstal or abstal demonstrate an expected syncope not seen in this case; due to this, as well as the similarity to the form apostolus that appears later in the text, I follow the recommendation of the reviewer and read apostol as signifying apostolus.

9 Apostolus appears in the manuscript as an abbreviation, rendered by Stokes and Strachan in the lectio codicis as $\underline{\mathrm{ap}}$ and expanded in the textus restitutus as apostolus: Stokes and Strachan, 2. Cambrai Homily, 246. 
From fol. 38a line 10, the homily transitions to a new subject and to what Ó Néill calls "Part II" of the homily: with filus trechenélae martre daneu, "now, there are three kinds of martyrdom ", the homilist introduces baanmatre ("white martyrdom"), glasmartre ("violet ${ }^{10}$ martyrdom«) and dercmartre (»red martyrdom«). The homilist describes baanmatre as abjuring one's loves or habits for the sake of God; glasmartre as abstinence from desire for such vices; and dercmartre as physical suffering for the sake of Christ. The description concludes with a statement that these three forms of martyrdom are contained in those "carnal ones" (i.e., humans) who observe these habits. This section contains only Irish, up until the phrase filus daneu trechenéle martre ata lógmára le Dea, aranetatham-ni fochrici ma nos-comalnnamar, "now, there are three kinds of martyrdom which are precious according to God for which we obtain rewards if we fulfil them ", which introduces a sequence in Latin: castitas in iuuentute, continentia in habundantia, "chastity in youth, continence in abundance". The homily ends here; the Latin that follows at this point in the manuscript is not the third form of martyrdom, but refers back to the text that the Cambrai homily initially interrupted. However, R. E. McNally recognised the first two elements in the triad as identical to another triad found in a mid-eighth-century florilegium known as the Prebiarum de multorum exemplaribus, ${ }^{11}$ so we may suppose that the final element would have been largitas in paupertate, »largesse in poverty«.

10 The precise interpretation of glas in this context, and whether this threefold concept of martyrdom was unique to Ireland or not, has excited some of the most vigorous debate surrounding the Cambrai Homily. Stokes and Strachan translate glasmartre as 'green martyrdom'; Stancliffe and Ó Néill prefer 'blue martyrdom'. In examining the Cambrai Homily alongside the Munich Commentary on Genesis (Clm 6302, fols. 49r-64r) and the Celtic Homily Collection (Vat. reg. lat. 49), Stancliffe observes that both of these latter texts contain colour interpretations, typically red (rubicundus) and white (candidus/albus), as well as blue (iacinthus) and occasionally yellow (millenicus) or black (niger). Stancliffe argues for a correspondence between glas and iacinthus, and on this basis she translates glas as blue, and furthermore identifies an association between iacinthus and penitence. Picard largely supports this analysis, but adds that while iacinthus or hyacinthus denoted 'blue' in Latin, in a biblical context it referred to violet ('the natural colour of the hyacinth flower', according to Picard), and that in Irish exegesis, the colour violet is associated with penitence, youth, abstinence, and the physical pain derived from manual labour. Both Stancliffe and Picard identify blue/violet martyrdom as a step up, so to speak, from white or quotidian martyrdom; in his observations on the colour hyacinth, Ó Néill also points out that - in patristic as well as Irish exegesis - it is associated with »a separation from earthly desires to turn to heavenly ones«. Stokes and Strachan, 2. Cambrai Homily, 247; Ó Néill, Background, 142-143; Picard, L’Homélie de Cambrai, 30-32; Stancliffe, Red, white, and blue, 22-29; for white martyrdom, see additionally Ní Chatháin, A reading, 417.

11 The Prebiarum triad in its entirety reads: Quod sunt genera martyri preter mortum? Id, tres. Continentia in habundantia, largitas in paupertate, castitas in iuuentute, "What are the kinds of martyrdom? That is, three. Continence in abundance, generosity in poverty, chastity in youth." Robert E. McNally and Charles Wright imply that these are two instances of the same triad, but Ó Néill cautions that because the Prebiarum is a florilegium, and a somewhat miscellaneous collection at that, it provides no clues about the context of this triad or its precise relationship to the Cambrai Homily: McNally, Scriptores I, 163; Wright, Irish Tradition, 74; Ó Néill, Background, 143. 


\section{Irish-Latin Interactions}

Irish-Latin Interactions in the Cambrai Homily

Although the Homily begins with an invocation and Scriptural citation in Latin, we may immediately observe that the overall matrix language is Irish; i.e. it is the base language into which Latin is embedded. ${ }^{12}$ The initial switch from Latin to Irish occurs at the end of the quotation, with the Irish beginning with a referential but independent clause (insce inso asber ar féda Ísu..., »this [is] the word our Lord Jesus says..."). The homilist's switch from Irish to Latin takes place at a clause boundary and is similarly marked (isaire asber, »therefore he says«).

Thereupon follows a series of intrasentential switches between Latin and Irish, wherein the Scriptural quotation is repeated, but interrupted with translations in Irish. For the purpose of illustration, it is worth quoting the passage once more in full:

Siquis uult post me uenire abneget semet ipsum et tollat crucem suam ocuis ticsath a chruich et sequatur me ocuis numsechethse

„If any man will come after me, let him deny himself, and take up his cross, and let him take up his cross, and follow me, and let him follow me."

We may note firstly that the quotation receives only a partial translation: the homilist only translates "let him take up his cross " and "let him follow me«. Rather than insertions, these appear to be instances of intrasentential alternations, which integrate semantically from a translational perspective, but are nevertheless syntactically independent. Despite the sequential alternations of phrases, there is no clash between grammars or morphosyntactic patterns. The homily continues in Irish, expanding on self-denial (»this is our denial of ourselves") and bearing one's cross ("this is our taking up of the cross upon ourselves").

At the subsequent clause boundary we find amail assindber alaile, "like a certain person says it ", which introduces the quotation in Latin; of the two quotations from Paul that follow, the first is introduced in Latin (ut Paulus ait, "as Paul says"), while the second is offset by the Irish ocus asbeir daniu ind apostol, "and furthermore the apostle says«. As mentioned above, however, despite Stokes and Strachan rendering the final word as Irish, it is more likely a ligature form of the Latin apostolus. The clause following the second Pauline quotation continues in Irish. The next switch from Irish to Latin follows a familiar pattern: it is marked by the Irish phrase amail assindbeir apostolus, "like the apostle says it«. Nevertheless, the next clause begins a quotation in Latin. Switches following this pattern (Irish to Latin switches marked by a speech tag), including this one, switch back from Latin to Irish at the conclusion of the quotations unmarked.

The final Irish-Latin switch, the presentation of the three (in the extant homily only two) forms of martyrdom treasured by God, is not marked with a speech tag. As noted in the presentation of the homily above, a very similar phrase is used to introduce the Latin text as was used earlier to introduce the red, white, and glas martyrdom described in Irish. The switch is intrasentential but occurs at a clause border and thus creates no grammatical or morphosyntactic clashes.

Erman Boztepe points out that the Myers-Scotton guideline of identifying the matrix language as the language of more morphemes is not unproblematic; however, in this case, not only is the volume of Irish noticeably greater but the Latin is used almost exclusively (with few exceptions) for quotations: Boztepe, Issues in code-switching, 10. 
Nicole Müller has argued that, in the Commentary to the Félire Oengusso and Bethu Brigte, it is relatively uncommon for code-switching to occur within a phrase. Müller notes that code-switching is more likely to be tolerated by a certain text when the information directly marked by the change does not affect the completeness of the sentence predicate. ${ }^{13}$ This appears to be the case when reading apostolus rather than apstol in the two examples above: it shifts the Irish-Latin switch from the clause boundary to within the clause, yet this involves a word that is similar in both languages, and aside from the syncope in Irish, both appear very similar in their nominative singular forms (particularly when abbreviated). These appear to be the only cases where a switch at a speech tag does not seem to align with the clause boundary.

\section{Irish-Latin Interactions in Medieval Ireland}

Irish and Latin enjoyed a particular relationship in medieval Ireland. As a biblical and sacral language, as well as the language of the learned class, there is no doubt about the authority, high status and cultural pre-eminence of Latin. Nevertheless, numerous Irish and bilingual texts demonstrate that Irish appears to have been seen as an important tool of communication. ${ }^{14}$ Certainly this was the case for in-group communication within the Irish-language community; however, the proliferation of manuscripts with texts in Irish copied on the Continent (and with more comprehension than the copyist of the Cambrai Homily) would seem to indicate that its importance was appreciated outside of Ireland as well. Thus, while the diglossic relationship between Latin and Irish may have begun as the $\mathrm{H}$ (high-status) and L (low-status) varieties present in the language community of the learned elite, over time the relationship became more complex as Irish clearly »leaked « into domains previously reserved for Latin. ${ }^{15}$ Jacopo Bisagni describes this relationship as one wherein the L variety (Irish) may be treated as a quasi-H variety within specific domains. ${ }^{16}$ His working hypothesis based on the Old Irish glosses is that switching from Irish (whether L or quasi-H) to Latin $(\mathrm{H})$ may, in fact, have been a common linguistic behaviour in early medieval Irish monasteries. ${ }^{17}$ Furthermore, these glosses contain such a diversity of code-switching patterns that Bisagni suggests there may have been a corresponding variety configurations of bilingualism. ${ }^{18}$ In her study on code-switching in Irish translation literature, Nicole Müller also argues that writers who spend most of their working time with both Latin and Irish texts might get accustomed to using certain languages for certain phrases and might mix the borders of the two language systems in cases where a particular phrase fits the syntactic structure of Latin as well as Irish. ${ }^{19}$ Within the Cambrai Homily, we certainly see the high prestige of Latin as

Müller, Kodewechsel, 77-78.

Bisagni, Prolegomena, 15-16; Bronner, Codeswitching, 3.

Fishman, Societal Bilingualism.

Bisagni, Prolegomena, 16.

Bisagni, Prolegomena, 37.

Bisagni, Prolegomena, 52

Müller, Kodewechsel, 79. 
the language of scriptural and patristic quotation; however, as the language of the body of the Homily, Irish clearly occupies a quasi-H status rather than one of low prestige. As noted above, speech tags regularly mark the switch from Latin to Irish (one case) or from Irish to Latin (four cases), and the switches, aside from the ambiguous abbreviation, occur either at phrasal or clause boundaries, thus keeping the borders of the language systems distinct.

It is worth noting, however, that in Bisagni's material (i.e., the Würzburg Irish glosses) Irish-Latin code-switching most often took the form of insertional switches; that is to say, they consisted mostly of the insertions of single lexemes in the matrix language. ${ }^{20}$ The Cambrai Homily, roughly contemporaneous and possibly earlier than the glosses, favours a type of mixing that aligns more with alternation: the elements surrounding the switches are usually not grammatically linked or morphologically integrated in the matrix language, as in cases of insertion, and the length and complexity of the switches also indicate alternation. This it has in common with later bilingual Irish-Latin material, such as the Vita Tripartita Sancti Patricii, ${ }^{21}$ and the Commentary to the Félire Oengusso. ${ }^{22}$ This potentially challenges Nike Stam's suggestion that the contrast between the strong, almost exclusive, preference for insertion in the Old Irish glosses and the preponderance of alternation in the Commentary to the Félire Oengusso may be explained by the progression of a bilingual community from one pattern to the other, as it suggests that both patterns may have been in place coterminously, but applied differently in different contexts. ${ }^{23}$ On the other hand, however, Stam notes that one of Muysken's features of alternation is that the two languages exist in competition with each other, and suggests that the change during the medieval period from Latin to Irish as the dominant literary language implies a long-standing competition between Latin and Irish. ${ }^{24}$ The early date of the Cambrai Homily, and the presence of alternation switches, supports this hypothesis and suggests that such competition between Latin and Irish had already begun by the end of the seventh century.

In medieval Irish code-switching, Stam and Tom ter Horst have discussed the importance of visual diamorphs, or words that by their form could potentially be assigned to either language in a bilingual situation. While often defined at the level of the word (for example, medieval Latin and Irish share certain conjunction diamorphs), Stam and ter Horst suggest that formulaic phrases may function as visual diamorphs as well. In their article, they describe the importance of visual diamorphs for neutralising the codes involved in code-switching. ${ }^{25}$ In this case, although the Cambrai Homily contains direct scriptural quotation, such highly formal language does not act as a phrasal visual diamorph. Ambiguous abbreviations are often visual diamorphs; however, the abbreviation $\underline{a p}^{\sim}$, and possibly even apostol, appear within the context of a speech tag which normally marks an Irish-Latin switch within this piece of writing. Thus, the role that they play in the switches, and indeed the Irish clauses, where they appear is somewhat ambiguous. The overall lack of visual diamorphs in this particular text, 
in contrast to their presence elsewhere in medieval Irish material, may be a function of the early form of Irish-Latin alternation present in the Cambrai Homily. In other words, at the time when the Cambrai Homily was written (if we presume that the copyist would have been unlikely to include such elements independently), visual diamorphs may not have had the importance for medieval Irish code-switching identified by Stam and ter Horst. However, it may also be an indication that the homilist wanted to play up the contrast, or the competition, between Irish and Latin within the Homily: the lack of neutrality and uneven status between these two codes indeed forms part of the power of the switch.

\section{Multilingual Practices in the Cambrai Homily}

Among the learned elite in early medieval Ireland, we may be confident in speaking of a "leaky" diglossic community in which many (if not all) members are at least partially bilingual. Regarding early medieval Ireland, we have, as mentioned above, early attested evidence of single works that include both Irish and Latin elements. ${ }^{26}$ Indeed, Irish-Latin bilingualism has excited a rich body of scholarship. ${ }^{27}$ With the exception of Picard, however, much of this research has tended to overlook the Cambrai Homily, and studies of the Cambrai Homily do not tend to linger on the Irish-Latin interactions within it. The quotations in Latin are typically identified as authoritative invocations, and the Irish that follows is generally interpreted as intended to translate this community's $\mathrm{H}$ variety into their $\mathrm{L}$ variety for an audience whose own bilingualism was too underdeveloped to understand the former. Ó Néill, as mentioned above, writes that the functions of Irish and Latin within the Cambrai Homily suggest an audience who would not have understood Latin. While he does observe that the content suggests a monastic or mixed audience, that he leans towards a mixed, rather than monastic, audience would seem to indicate that he still sees the code-switching as serving that purpose, even if part of the audience (i.e., the monks) would not have needed it. ${ }^{28}$ Picard, who resists even further the implication that the homilist anticipated an audience (possibly a lay audience) with insufficient Latin, has suggested that the Irish-Latin interactions in the Cambrai Homily served to elucidate difficult concepts in a style reminiscent of the glosses created around that time. ${ }^{29}$ Thus, the

passage du latine à la langue maternelle devient alors un moyen de clarifer ses idées et de proposer au groupe une interprétation dont on a éliminé au moins l'équivoque de la transposition culturo-linguistique. ${ }^{30}$

While the Cambrai Homily is argued to be the oldest piece of continuous prose in Irish, the earliest attested bilingual material from Ireland is likely to have been the Old Irish glosses (eighth century). For more on Irish-Latin bilingualism in the Old Irish glosses, see, e.g., Bisagni, Prolegomena and Bisagni and Warntjes, Early Old Irish material.

27 See, for example, Bisagni, Prolegomena; Bronner, Codeswitching; Stam, Typology; ter Horst, Code-switching; Picard, L’Homélie de Cambrai; Müller, Kodewechsel.

28 Ó Néill, Background, 144-145. Although Picard revises Ó Néill's ideas somewhat, the general suggestion (i.e., the Irish being necessary to explain the Latin to some degree) persists. Picard, L'Homélie de Cambrai, 33.

29 Picard, L'Homélie de Cambrai, 33; supported by Bisagni, Prolegomena.

30 Picard, L'Homélie de Cambrai, 34: »[The] passage from Latin to one's mother tongue thus becomes a way to clarify its ideas [i.e., those of the Latin text] and to propose to the group an interpretation where the ambiguity of the cultural-linguistic transposition has at least been removed« [trans. author]. 
While this is certainly a plausible interpretation of the Irish-Latin interaction within the Cambrai Homily in broad terms, and one which will be returned to in greater detail below, it does not give due consideration to the variations in Irish-Latin interaction that we observed in the previous section. The situation is not as simple as the "passage from Latin to one's mother tongue", and an analysis of the code-switching that takes place in the Cambrai Homily should attempt to account both for the variations in switches that take place, and for the interplay between the Latin quotations and Irish matrix. In the sections that follow, I will first interrogate a group of concepts that sit at the intersection of translation and code-switching analyses, with a particular focus on quotation, reiteration and support. Then, I will analyse the multilingual practices in the Cambrai Homily to see whether these concepts may facilitate our attempt to account for the code-switching within the homily and the motivations or goals of the homilist in including them, and as a consequence enrich our understanding of the sociolinguistic context in which the text was produced.

\section{Quotation, Reiteration, and Support}

Although translation and code-switching are both features of multilingual practices, they have usually been thought to have different functions and apply to different rhetorical situations: According to this way of thinking, translation is the (more or less) word-for-word substitution of one language for another, whereas code-switching is the presence of more than one language or dialect within the same sentence, conversation, or piece of writing. ${ }^{31}$ However, it may be more appropriate to see translation and code-switching as occupying a continuum of multilingual practice, whereby, depending on the participants, their language competence, and the particular sociocultural context of language use, these two language processes are not only connected, but actively interact with each other. ${ }^{32}$ Quotation is, in and of itself, not necessarily a feature of translation studies, as direct quotations or reported speech do not implicitly require translation or explanation, though the function of code-switching to frame a quotation - sometimes twice, with not only a change in language but also a quotative verb - is well known. ${ }^{33}$ In particular, it is common to find quotations accompanied by code-switching in medieval sermons or homilies featuring Latin quotations. Frequently, these appear with vernacular translation, paraphrase, or elaboration. ${ }^{34}$ Thus, quotation is an important element of both reiteration and support, two functions of code-switching that frequently feature translation (or features of translation that frequently result in code-switching, depending on one's perspective).

The interaction between translation and code-switching that occurs in cases of reiteration within written works is grounded in the presence of translation in the text (intra-textual), rather than in between different texts (inter-textual). ${ }^{35}$ Gumperz identifies (translational) reiteration as the repetition of an expression in another language or code in a more or less 
modified form, and this definition generally serves as the basis for studies of reiteration which have followed.$^{36}$ Katariina Harjunpää and Aleksi Mäkilähde have observed that where participants know the same languages, translational reiteration does not necessarily serve to ensure mutual understanding; in addition to cases of reiteration with a facilitating function, Harjunpää and Mäkilähde provide examples where the speaker using reiteration treats the prior reference (i.e. the thing being reiterated) as linguistically accessible to their audience. ${ }^{37}$ Aside from clarification, two widely recognised functions of reiteration in general, and translational reiteration in particular, are emphasis and amplification. With reference to medieval English drama, Diller has argued that biblical Latin was used to show that a »thought has already been expressed and presumably in its definitive form, ${ }^{{ }^{38}}$ and the biblical Latin appearing in sermons and homilies not only pointed to the sacredness of the words, but also provided the audience with structural cues. The vernacular reiteration, in fact, contained the main message. ${ }^{39}$ Furthermore, when analysing medieval material, we would do well not to forget the debt that was owed to classical rhetoric and its role in the education of the learned class. Reiteration is a prominent figure within classical rhetoric, and one which students would likely have encountered, even though that familiarity would have been mediated by means of late antique rhetorical literature and handbooks rather than direct knowledge of classical rhetorical teaching. ${ }^{40}$ The reiterative character of quotations and their translations thus has a potentially classical, or late antique, referent, as well as an established didactic function. Additionally, Harjunpää and Mäkilähde observe »in examples from prior studies and in our data, " translational or code-switched reiterations often appear adjacent to or in connection with reiterated utterances lacking any translational or code-switched element. ${ }^{41}$

In his study of medieval English drama, Diller explores forms of translation and paraphrase, though, as Harjunpää and Mäkilähde point out, he does so without broader reference to repetition or reiteration as a more general phenomenon..$^{42}$ Instead, he introduces the term "support « to characterise instances where English paraphrases, elaborates, or translates text in Latin. In all cases, the function of clarification is seen to be the unifying feature. Using the code-switching within the multilingual text Vices and Virtues in MS Stowe 34 from c. 1200 as an illustrative example, Janne Skaffari has explored and elaborated upon Diller's concept

36 Gumperz, Discourse, 78.

37 Harjunpää and Mäkilähde, Reiteration, 174.

38 Diller, English drama, 510, emphasis in original.

39 Harjunpää and Mäkilähde, Reiteration, 182.

40 For the prominence of repetition within classical rhetoric, see Harjunpää and Mäkilähde, Reiteration, 185 and Vickers, Repetition, esp. 90-93. For a more theoretical examination of the role of ornament (including tropes of repetition, classed under ornamentations of orderliness and pattern) in making "mnemonically powerful associations «, see Carruthers, Craft, 117. For the intersection of reading, writing, and memory in an early medieval Irish context, and particularly potential mutual connections between literacy and orality, see Johnson, Literacy, esp. 162-164. For the presence of rhetorical teaching in early medieval Ireland, with specific reference to the late antique rhetorical literature and handbooks that informed the composition of the Hisperica Famina, see Knappe, Rhetoric and Grammar. Knappe, Classical Rhetoric, is also relevant here, although this paper deals more specifically with the early English context.

41 Harjunpää and Mäkilähde, Reiteration, 194.

42 Diller, English drama; Harjunpää and Mäkilähde, Reiteration. 
of "support", noting its similarity to the terms "cushioning " and "parallelism « used in translation studies. In "cushioning «, a term which originated in postcolonial literature, words or phrases in a foreign language are accompanied, or "cushioned «, by equivalent expressions in the text's primary language..$^{43}$ "Parallelism « describes "textual components expressing the same content in different languages « (e.g. bilingual signs). ${ }^{44}$ Skaffari sees these terms as lacking currency in studies of historical code-switching, and turns to the concept of »support « as a way to express both the sense of equivalence carried by "parallelism « and that of "softening the blow« of the presence of an unfamiliar language provided by »cushioning «. As Skaffari explains,

[The] function of the support is to facilitate understanding in case the reader or audience does not know the embedded language well enough to access meaning expressed in that language. ${ }^{45}$

Diller and Skaffari both view reiteration as falling broadly under the heading of support, and in instances of translational reiteration, quotations in a non-matrix language are clear targets for supportive elements in the matrix language. Here too the functions of amplification and emphasis are recognised but, especially in the case of amplification, subsumed under elaborative support. However, as Skaffari notes, »if the reader ignores the [code-switch] in favour of the support, what is left is no longer reiteration from the reader's point of view, as nothing is repeated. ${ }^{46}$

Both translational reiteration and support coalesce around functions of clarification, emphasis/amplification, and translation. They are broadly similar approaches to translational and paraphrased code-switches; the major difficulty with applying support as an explanatory model is that, as a recently introduced and comparatively underdeveloped analytical concept, it remains somewhat imprecise, and its inclusivity makes hazy certain distinctions (such as, indeed, reiteration and translation) that vary in discreteness depending on a variety of factors, such as what the code-switch achieves, or speaker as well as listener language competence. In other words, precisely how the code-switched element clarifies or facilitates understanding remains unclear. Harjunpää and Mäkilähde point out that the apparent occurrence of a word-for-word translation does not necessarily indicate the rendering of an utterance in another language to facilitate participant interaction; what is important is "what the modification achieves in its specific interactional context. « ${ }^{47}$ They highlight the fact that in some cases, the role of the original "saying " can be more complex than simply acting as a target for emphasis, translation, or clarification, whereby the message in fact relies on the "combination of original and reiterated items embedded in the larger activity «. ${ }^{8}$ Indeed, the degree to which the Irish text "supports" (according to Diller and Skaffari) the Latin quotations in our text will depend largely upon the way in which Irish and Latin are combined within the »activity« of the Homily. 


\section{Reiterative and Supportive Code-switching in the Cambrai Homily}

We may immediately observe that, despite the variation of interactions between Irish and Latin in our text, it follows a rather restricted switching pattern whereby the only elements in Latin are scriptural or patristic citations. The initial Latin citation is, of course, the invocation and pericope; i.e. the passage from Scripture that forms the basis of the homily. From the invocation to the Gregorian citation, i.e. the first half of Ó Néill's Part I discussed above, the homilist's interpretation remains close to the text of the pericope; the quotation from Gregory the Great's homilies connects the theme of "carrying one's cross « to the practices of abstinence and fellow-suffering, thus bridging this half of Part I with the second (fellowsuffering), as well as with Part II (forms of martyrdom, including abstinence).

We have touched upon the conventions of the homiletic genre above; at this point we may pause for a moment and consider precisely what form this genre took in the later seventh and early eighth centuries. Throughout much of the Middle Ages, the two most common labels for written works recording preaching, sermo and homilia ("sermon« and "homily«, respectively) were often used interchangeably; the distinction between the two terms as denoting more or less discrete styles of discourse is a scholarly tendency. ${ }^{49} \mathrm{~A}$ homily presents a passage from Scripture (the aforementioned pericope), and reads a word or phrase at a time while explaining and offering commentary. In principle the explanation and commentary should centre on the fourfold sense of scripture; i.e., the historical (the words and events within Scripture); the spiritual or allegorical (symbols in this world that reflect divine will); the moral (practical application); and the anagogical (guiding the listener or reader towards heaven).$^{50}$ Ter Horst points out that in the "Ancient form « (i.e. the homiletic form most often observed during the early Middle Ages through the long twelfth century) this fourfold system frequently collapsed into a simplified literal sense (the text of Scripture and its translation into the vernacular) and spiritual meaning (in effect everything else), and that this simplified system is often found in homilies intended to be preached before an audience.$^{51}$ Additionally, Thayer notes that while the biblical text provides the framework of a homily's discourse, the preacher did not necessarily need to stay close to the text, often resulting in "tangents or digressions . $^{52}$

The structure of the Cambrai Homily aligns with the "Ancient form" described above, whereby the homilist explains the words of the pericope and then moves on to an explanation and commentary that combines the spiritual and moral senses. Whether the homily would have ended with an eschatological sense is impossible to know for certain. Nevertheless, the difficulty in applying the concept of support to interpret code-switching in the Cambrai Homily becomes immediately apparent: as a genre, the homily's central aim is to clarify and explain Scripture. Regarding homilies in the vernacular, the importance of translation in carrying out this aim is clear; what is less straightforward, however, is the extent to which explanations in the vernacular serve to explain the Latin, Scripture, or both. This 
will naturally vary case by case, and depend upon the Latin competence of the homilist, the expected Latin competence of the audience and, correspondingly, whether they, as a group, were lay or monastic. In the case of the Cambrai Homily, both the intricacy of the commentary and the internal references between Irish and Latin elements suggest that the homilist presumed his audience would understand the Latin of the citations, even if their message required explication. Picard's argument that the Homily was created for a monastic audience seems reasonable, and given not only the largely diglossic character of Irish monasticism at this time but also the predominance of Latin as the primary language of the Church, the extent to which Latin elements in a homily would have required "cushioning « is questionable. I would thus propose that while the Irish commentary certainly supports and clarifies the Latin citations of Scripture and Gregory the Great, it most likely does not do so on the level of code-switching. Indeed, it seems more likely that the abrupt contrasts between Latin citation and Irish commentary serve to highlight the change in language rather than explain it.

Thus, while support holds potential as a framework for understanding code-switching in medieval texts, it requires a more precise framework and must be applied on a case-to-case basis. Does translational reiteration experience the same challenges? As mentioned above, the only direct translation in the text appears quite early on: the framing quotation is given in Latin, followed by the identification of the speaker (Jesus Christ) and his audience (humankind), as well as a paraphrase in Irish; then, the homilist translates the quotation once more, phrase by phrase. Structurally, the homilist takes some liberties with the phrase-by-phrase translation, skipping abneget semet ipsum in order to translate and expand on this part of the biblical quotation following the phrase-by-phrase translation. More than translation, however, the repetition in this small section achieves two important elements: firstly, through reiteration in two languages the homilist amplifies the citation from Matthew, the core message of the homily. Secondly, by dividing the citation into phrases and repeating each phrase first in Latin then in Irish, the homilist communicates to their audience the structure of the homily to follow. The switches between Latin and Irish highlight and establish Latin as the signal for authority and definitive reference, and Irish as the signal for commentary and interpretation. This sets up the pattern of code-switching throughout the remainder of the homily: although lacking in reiteration, it retains the emphatic and signalling character of the initial switches between the Matthew quotation and its Irish translations.

If we posit a function of translational reiteration to the Irish-Latin interactions in this initial section of the Cambrai Homily, we may ameliorate the apparent inconsistency between the function of the Irish-Latin codeswitching and the supposed monastic or mixed audience of the Homily, and thus clarify some of the sociolinguistic underpinnings of the homily itself. Irish and Latin clearly have their own domains in this text, but given the deftness of the homily's Irish commentary - indeed, Ó Néill notes that the homilist "shows a fine awareness of his craft ${ }^{53}$ - it seems reasonable to interpret this relationship as closer to an $\mathrm{H}$ and quasi- $\mathrm{H}$ interaction between Latin and Irish, respectively, than an $\mathrm{H}$ and L interaction as previous analyses have implied. Interpreting the repetitive translation of the framing biblical quotation as a deliberate emphatic strategy, and one which would provide a listening audience 
with structural cues akin to present-day signposting strategies, supports such a characterisation of Irish-Latin interaction. The convincingly argued state of Irish monastic diglossia and well-attested high status of Irish as a language of religious writing by the eighth century also supports a more subtle and rhetorically-grounded use of reiteration by the homilist.

\section{Conclusions}

This paper has re-evaluated the Irish-Latin code-switching in the Cambrai Homily according to two particular language-interaction paradigms, vernacular support and translational reiteration. Ó Néill initially suggested that the relationship between Irish and Latin was one of translation for an audience with a defective or insufficient knowledge of Latin, and it appears that he suggests a mixed (rather than monastic) audience for the Homily on this basis. Although Picard has modified this view, he describes the Irish elements as intended to explain or facilitate the comprehension of complex themes expressed in Latin. However, he also argues that the audience was likely monastic (rather than mixed), and thus unlikely to have been lacking in Latin competence. The Irish-Latin interactions as described by Picard align closely with the concept of language interaction coined by Diller as "support«, and expanded on by Skaffari. Vernacular support also aligns closely with the genre conventions of early medieval homilies more generally, and in the case of vernacular homilies that contain Latin quotations, it can be challenging to parse the degree to which the clarification contained in the vernacular text acts upon the content of the Latin citation, versus facilitating understanding an unfamiliar language.

As an alternative, the present paper approached the language interaction of the Cambrai Homily rhetorically, and sought to account for the Irish-Latin switches in a way that could accommodate both the asserted diglossic nature of early medieval Irish monasticism, and the clear presence of translational elements within the homily. Translational reiteration not only combines aspects of translation studies and code-switching, but also accommodates the rhetorical value of reiteration. Granted, this applies to a small section of the homily, but I would argue that it sets a pattern of switching (through establishing the switches as points of emphasis as well as establishing the domains of Irish and Latin respectively) that is followed throughout.

It is hoped that this reassessment of an early example of Irish-Latin code-switching may hold some interest for research in language interaction. Although the switching pattern of the Cambrai Homily is more rigid than is seen in other genres, and later texts within the homiletic genre itself, it nevertheless demonstrates the usefulness of occasionally looking beyond the boundaries of code-switching to related fields such as translation studies and rhetoric.

\section{Acknowledgement}

I am grateful to the peer reviewer for their valuable comments and corrections. Any errors that remain are, of course, entirely my own. 


\section{References}

\section{Manuscript}

Cambrai, Bibliothèque municipale, MS 679.

Bisagni, Jacopo, Prolegomena to the study of code-switching in the Old Irish glosses, in: Peritia 24-25 (2014) 1-58.

Bisagni, Jacopo and Immo Warntjes. The Early Old Irish material in the newly discovered Computus Einsidlensis (c. AD 700), Ériu 58 (2008) 77-105.

Boztepe, Erman, Issues in code-switching: Competing theories and models, Teacher's College, Columbia University Papers in TESOL \& Applied Linguistics 3/2 (2003) 1-27.

Bronner, Dagmar, Codeswitching in medieval Ireland: The case of the Vita Tripartita Patricii, Journal of Celtic Linguistics (2005) 1-12.

Carruthers, Mary, The Craft of Thought: Mediation, Rhetoric, and the Making of Images (Cambridge, 1998).

Diller, Hans-Jürgen, Code-switching in medieval English drama, Comparative Drama 31/4 (1997-1998) 506-537.

Fishman, Joshua A., Societal bilingualism: stable and transitional, in: Anwar S. Dil (ed.), Language in Sociocultural Change (Stanford, CA, 1972) 135-152.

Gardner-Chloros, Penelope, Code-switching (Cambridge, 2009).

Gumperz, John J., Discourse Strategies (Cambridge, 1982).

Harjunpää, Katariina and Aleksi Mäkilähde, Reiteration: at the intersection of code-switching and translation, Multilingua 35/2 (2016) 163-201.

Johnston, Elva, Literacy and identity in early medieval Ireland (Woodbridge, 2013).

Knappe, Gabriele, On rhetoric and grammar in the "Hisperica Famina", The Journal of Medieval Latin 4 (1994) 130-162.

Knappe, Gabriele, Classical rhetoric in Anglo-Saxon England, Anglo-Saxon England 47 (2008) 5-29.

Kolehmainen, Leena and Janne Skaffari, Multilingual practices in contemporary and historical contexts: interfaces between code-switching and translation, Multilingua 35/2 (2016) 123-135.

Mac Donncha, Frederic, Medieval Irish homilies, in: Martin McNamara (ed.), Biblical Studies: The Medieval Irish Contribution (Dublin, 1976) 59-71.

McNally, Robert E. (ed.), Scriptores Hiberniae Minores I (Turnhout, 1973).

Meylaerts, Reine, Multilingualism and translation, in: Yves Gambier and Luc van Doorslaer (eds.), Handbook of translation studies vol. 1 (Amsterdam, 2011) 227-230.

Müller, Nicole, Kodewechsel in der irischen Übersetzungsliteratur. Exempla et desiderata, in: Erich Poppe and Hildegard L. C. Tristram (eds.), Übersetzung, Adaptation und Akkulturation im insularen Mittelalter, (Münster, 1999) 73-86.

Muzerelle, Denis (ed.), Manuscrits datés des bibliothèques de France 1. Cambrai (Paris, 2000).

Ní Chatháin, Próinséas, A reading in the Cambrai homily, Celtica 21 (1990) 417.

Ó Flaithearta, Mícheál and Lars B. Nooj (ed. and asst. ed.), Code-Switching in Medieval Ireland and England: proceedings of a workshop on code-switching in the medieval classroom, Utrecht 29th May, 2015 (Bremen, 2018).

Ó hAnnracháin, Eoghan, Aguisín I: Homaile Cambrai, Irisleabhar Mhá Nuad (2010) 39-43.

Ó Néill, Pádraig P., Background to the Cambrai Homily, Ériu 32 (1981) 137-147. 
Picard, Jean Michel, L'Homélie de Cambrai: écriture biligue et traduction dans les milieux irlandais du VIIe siècle, in: Michel Ballard, Europe et Traduction (Ottawa, 1998) 25-36.

Stam, Nike, A Typology of Code-switching in the Commentary to the Félire Oengusso (Utrecht, 2017).

Stam, Nike and Tom ter Horst, Visual Diamorphs: The importance of language-neutrality in code-switching from medieval Ireland, in: Päivi Pahta, Janne Skaffari, and Laura Wright (eds.) Multilingual Practices in Language History: English and Beyond (Berlin, 2018) 223-242.

Skaffari, Janne, Code-switching and vernacular support: an early Middle English case-study, Multilingua 35/2 (2016) 203-226.

Stancliffe, Clare, Red, white and blue martyrdom, in: Dorothy Whitelock, Rosamund McKitterick and David Dumville (eds.), Ireland in Early Medieval Europe: Studies in Memory of Kathleen Hughes (Cambridge, 1982) 21-46.

Stokes, Whitley and John Strachan, Description of the MSS containing the glosses etc. printed in this volume, in: Thesaurus palaeohibernicus: a collection of Old-Irish glosses, scholia, prose, and verse, 2 (Cambridge, 1903) ix-xl.

Stokes, Whitley and John Strachan (eds.), 2. The Cambrai Homily, in: Thesaurus palaeohibernicus: a collection of Old-Irish glosses, scholia, prose, and verse, 2 (Cambridge, 1903) 244-247.

Ter Horst, Tom, Code-switching in the Irish-Latin Leabhar Breac: Mediæval homiletic culture (Utrecht, 2017).

Thayer, Anne T., The medieval sermon, in: Joel T. Rosenthal (ed.), Understanding Medieval Primary Sources: Using Historical Sources to Discover Medieval Europe (London, 2011) 43-58.

Vickers, Brian, Repetition and Emphasis in Rhetoric: Theory and Practice, in: Andreas Fischer (ed.), Repetition (Tübingen, 1994) 85-114.

Wright, Charles, The Irish Tradition in Old English Literature (Cambridge, 1993). 